\title{
A GIS-Based Suitability Analysis for Siting a Solid Waste Incineration Power Plant in an Urban Area Case Study: Alexandria Governorate, Egypt
}

\author{
Mahmoud A. Hassaan \\ Institute of Graduate Studies and Research (IGSR), University of Alexandria, \\ Alexandria, Egypt \\ Email: mhassaan@arca-eg.org
}

Received 10 November 2015; accepted 26 December 2015; published 30 December 2015

Copyright (C) 2015 by author and Scientific Research Publishing Inc.

This work is licensed under the Creative Commons Attribution International License (CC BY). http://creativecommons.org/licenses/by/4.0/

\section{(c) (i) Open Access}

\begin{abstract}
Solid waste represents a key issue that threatens environmental quality in Egyptian urban areas. One of the most viable options to treat such an issue is to incinerate the collected solid waste for electricity generation, which can reduce the cost of solid waste disposal as well as pollution and generate surplus energy. Selecting appropriate site for a solid waste incineration power plant is a crucial step due to its economic and environmental implications. This would require assessing various constraining and favorable factors that determine feasibility and sustainability of the power plant site. This paper is intended to develop a GIS-based model for siting a municipal solid waste incineration power plant in Alexandria governorate, Egypt. For this purpose, five criteria are considered and a composite index was suggested to integrate these criteria in a numerical term reflecting suitability of various parts of the governorate for siting solid waste incineration power plant.
\end{abstract}

\section{Keywords}

Suitability Analysis, Site Selection, GIS, Municipal Solid Waste, Alexandria, Egypt

\section{Introduction}

Municipal solid waste is considered to be one of the key issues that threaten environmental quality in urban areas in developing countries [1]-[3]. This is mainly due to the increasing quantities of generated municipal solid 
waste caused by ever increasing population, rapid urbanization and shifting consumption patterns [4]. On the other hand, limited solid waste management capacities, especially in developing countries, are exuberating the problem as well as its economic and environmental implications. It is worth mentioning that an efficient municipal solid waste management system is concerned not only with effective collection of generated municipal solid wastes but also with proper utilization of the solid waste in recycling, treatment or disposal in sanitary landfills [1].

One of the most viable options to treat properly municipal solid waste is utilization of solid waste for power generation. Generating power from solid waste through incineration involves reducing the cost of solid waste disposal and generating much needed energy. From environmental point of view as considerable proportions of municipal solid waste are organic matters that form part of a bio-cycle, therefore, converting wastes to electricity through combustion may not contribute to increasing $\mathrm{CO}_{2}$ concentration in the atmosphere [5]. Still, there is a need to carefully consider the conversion process in order to reduce any potential adverse impacts from the emissions that could be emitted.

Site selection for municipal solid waste incineration power plant is one of the essential steps to ensure the proper planning and implementation of such a plant. Generally, site selection for a certain activity requires conducting suitability analysis involving, based on the type of activity, a variety of criteria. The main objective of suitability analysis, in general, is to identify the most appropriate spatial pattern for future land uses by classifying various parts of the considered area according to their suitability for a particular activity [6]. This is done according to specific requirements and preferences of the proposed activity taking into account a number of constraining and favoring factors that represent the requirements and preferences of this activity.

Suitability analysis for siting municipal incineration solid waste power plant should consider mainly economic and environmental issues associated with its operation [7]. This means that the site of solid waste incineration power plant should contribute not only to ensure feasibility of the plant, but also to mitigate environmental adverse impacts that may be arisen from such a plant.

Generally, three main categories of criteria for siting solid waste incineration power plant are typically suggested; exclusionary, avoidance and suitability ones. Exclusionary criteria represent the requirements that should be satisfied by the site and whatever site is not satisfying these requirements should be excluded. Avoidance criteria are those requirements, which should be fulfilled, at varying degrees, by the site to mitigate annoying factors that may be resulted in by the plant. Meanwhile, suitability criteria represent those criteria that affect the relative suitability of different potential sites [8].

To conduct suitability analysis, there is a need to integrate wide range of spatial variables that represent different factors determining the location optimization [9]. For this purpose, GISs have been employed in suitability analysis due to their capabilities to deal with spatial data. In this context, it was argued that suitability analysis is one of the most valuable applications of GIS [6].

Despite that there is a considerable number of suitability analysis studies that have been undertaken for siting power plants applying GIS techniques, suitability analysis for siting municipal solid waste incineration power plants was rarely considered e.g. [10]. The power plants siting studies have mostly focused on siting nuclear power plants e.g. [11] and renewable energy power stations e.g. [12]-[17].

This paper is intended to develop a GIS-based model for siting solid waste incineration power plant in Alexandria Governorate, Egypt. Such a model, it is thought that, can support the sustainability of Alexandria city through proper treatment of solid waste issue and generating surplus electrical energy.

\section{Case Study}

Alexandria governorate is located to the north west of the Nile Delta on the Mediterranean Sea (Figure 1). The governorate includes the second largest urban center in Egypt with a total population of 4.6 million in 2012 [18]. Alexandria plays a major role in the Egyptian economy, as it hosts the main port in Egypt, which has about 75\% of the total capacity of Egyptian ports on the Mediterranean Sea. Alexandria also hosts 4417 industrial firms, employing about 201,000 workers. These firms produce about 40\% of Egypt's total industrial production [19].

Alexandria governorate covers a total area of $2416 \mathrm{~km}^{2}$, of which the built-up area of Alexandria city covers $440 \mathrm{~km}^{2}$, representing about $18.3 \%$ of total governorate area. The built-up area of the city has a longitudinal shape extending from northeast to southwest between the coastline and Lake Maryuit. This is mainly due to site characteristics. Also, wetlands, which represented in Lake Maryuit covers about $233.44 \mathrm{~km}^{2}$ accounting for $9.69 \%$ 


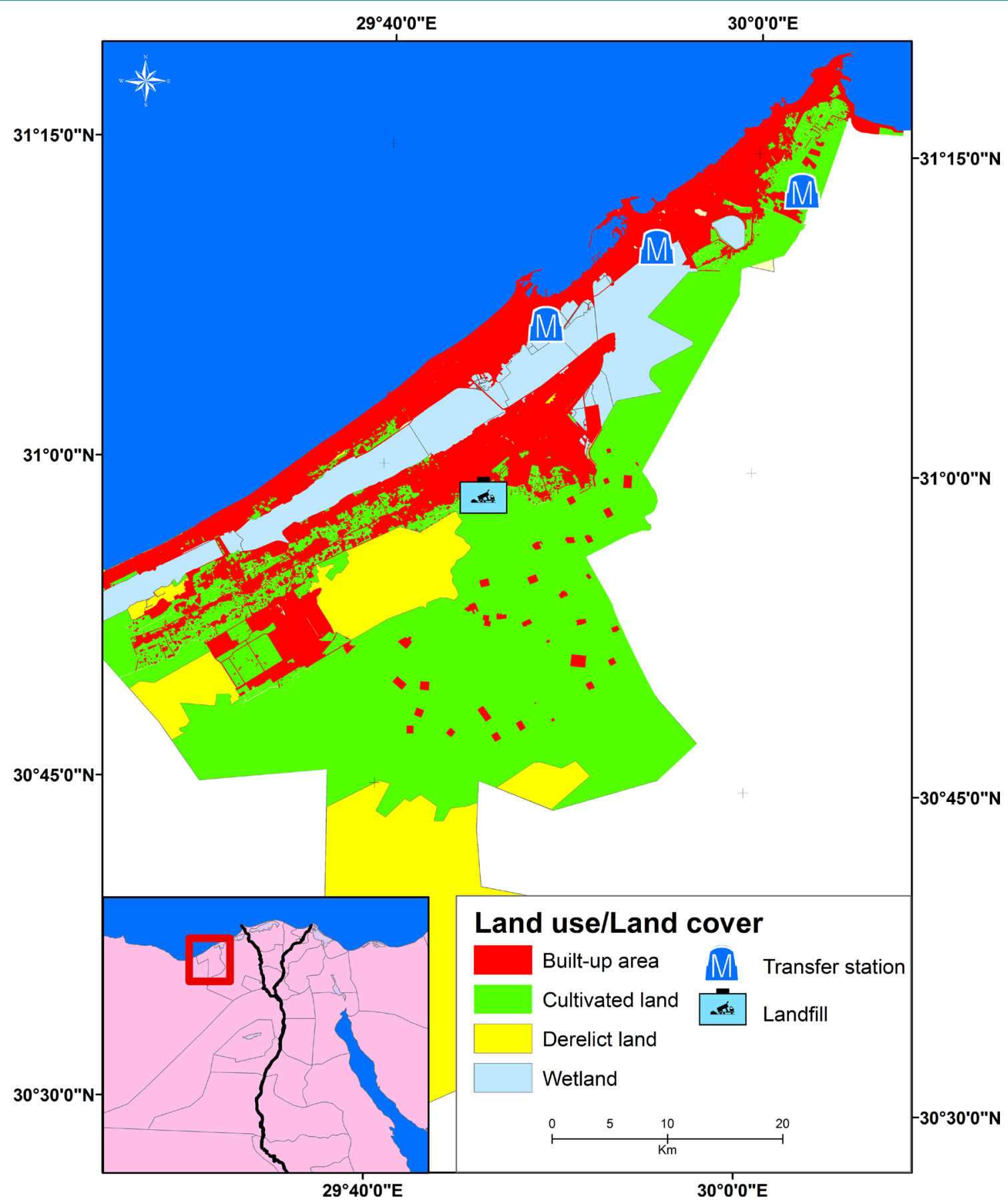

Figure 1. Land use/land cover of Alexandria governorate.

of the total governorate area. The southern parts Alexandria governorate is dominated by cultivated land, which covers about $40.15 \%$ of the total governorate area. Meanwhile, a considerable proportion (31.90\%) of the governorate area is derelict land that extends mainly in the southwestern parts of the governorate (Figure 1).

Alexandria as most Egyptian urban areas has been suffering accumulation of considerable quantities of solid waste in the streets [3]. The per capita municipal solid waste generation in Egyptian urban areas ranged between 0.7 - $1.0 \mathrm{~kg} /$ day [20], which means the total amount of solid waste generated daily in Alexandria was about 4000 tones. The collected municipal solid wastes are transferred to three transfer stations located in Mohamram Bek, Um Zeghu and El Montazah (Figure 1). Thereafter, the non-recyclable materials are transferred to a sanitary 
landfill in Burg El Arab to be disposed.

In reality, the illegal dumping and open burning of the solid waste are common practices in different parts of the city. Also, the solid waste collection coverage in Alexandria governorate is about 65\% [4]. This means that about 2600 tones of solid waste are collected daily. Such inefficient municipal solid waste management system adversely affects environmental quality in the city. Meanwhile, the city has been already suffering from electricity blackouts, especially in summer times, due to shortage in fuel supply forcing the government to reduce the loads on power grids. Utilization of solid waste for power generation, in such a case, can be seen as a reasonable option to treat solid waste properly.

\section{Methodology}

Site selection for the solid waste power plant in Alexandria governorate was carried out through a four-steps methodology (Figure 2).

1) Identifying siting criteria

The site selection decision for the solid waste incineration power plant should consider a wide range of factors that ensure selecting not only appropriate locations but also the most optimal one for the plant [9]. Accordingly, for the purpose of this study, the following criteria were identified (Table 1).

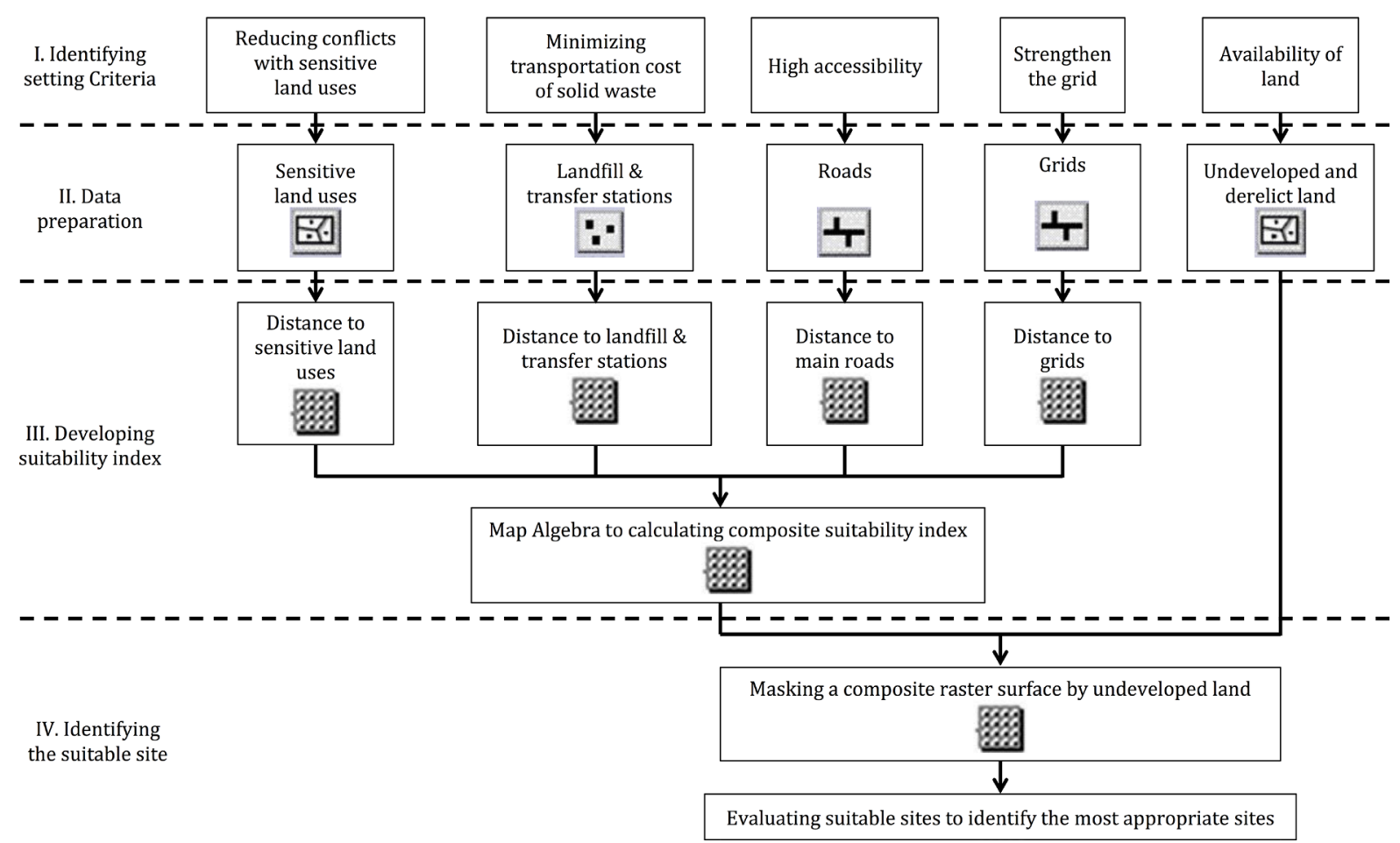

Figure 2. Methodology for solid waste power station site selection.

Table 1. Criteria for site selection of solid waste incineration power plant.

\begin{tabular}{lll}
\hline Criteria & Variable & Description \\
\hline Minimum operation cost & $\begin{array}{l}\text { 1) Distance to landfills and transfer stations. } \\
\text { 2) Distance to main roads }\end{array}$ & $\begin{array}{l}\text { The closer sites are better due to reduced } \\
\text { transportation costs. }\end{array}$ \\
$\begin{array}{l}\text { Proximity to the electrical } \\
\text { grid }\end{array}$ & 3) Distance to Electrical grid & $\begin{array}{l}\text { The closer sites are better due to reduced } \\
\text { transportation costs. }\end{array}$ \\
$\begin{array}{l}\text { Minimum conflicts with } \\
\text { sensitive land use }\end{array}$ & $\begin{array}{l}\text { 4) Distance to sensitive land uses (e.g. residential, } \\
\text { educational services, medical services, etc.) }\end{array}$ & $\begin{array}{l}\text { The more distant sites are better to avoid noise, odor } \\
\text { and other annoying factors. } \\
\text { Land availability }\end{array}$ \\
\hline
\end{tabular}


- Minimum operation cost

A relatively large proportion of the operational cost of the power plant is associated with solid waste transportation, which in turn can affect the economic feasibility of the power plant [9] [10]. Minimizing transportation cost, in the case of the solid waste incineration power plant, entails selecting sites that are relatively close to the potential sources of solid waste [7] [21]. Also, Minimizing transportation cost can be attained by highly accessible sites that ensure steadily supply of solid waste [10].

Accordingly, the site of solid waste incineration power plant is preferable to be close to main roads and close to landfills and/or transfer stations as potential source of solid waste.

Nearness to landfill is also crucial in the case of solid waste incineration power plant for disposing residues [7]. Yet, It should be noted however that considering landfills and/or transfer stations as potential sources of solid waste for the power plant assumes efficient solid waste management and consequently high levels of solid waste collection.

- Proximity to the electrical grid

To ensure proper utilization of the generated electricity, the solid waste incineration power plant needs to be located in sites that are close to the existing electricity grid [7] [10] and where connections may be made.

- Minimum conflicts with sensitive land use

Some nuisance factors, such as odor, noise or emissions could not be avoided in the case of the solid waste incineration power plant. This means that selected sites should be located away from sensitive land uses e.g. residential areas, educational and health services, etc. [7] [10] [21]. This, consequently, implies that the longer the distance between the power plant site and sensitive land uses is the better in order to avoid and/or mitigate the adverse impact of these annoying factors.

- Availability of land

The site of solid waste incineration power plant should not be currently used or allocated for a certain activity. This means that the selected sites should be within the vicinity of undeveloped or derelict lands.

2) Data preparation

This step involves representing each assessment criterion spatially in a GIS layer. For this purpose, land use pattern, roads, electricity grids were digitized from topographic map scale 1:50,000 for Alexandria. This includes the delineation of land use patterns highlighting the built-up area of the governorate and sensitive land uses such as residential areas as well as educational, health care services... etc. This also involves delineating undeveloped or derelict parcels of land as well as the locations of landfill and transfer stations of the solid waste.

Thereafter, these vector layers were utilized in creating a number raster surfaces that represent the spatial variations of each criterion within the boundaries of Alexandria governorate. Through GIS, Euclidean Distance Tool, a number of raster surfaces representing distance to landfill and transfer stations as most potential sources of solid waste, distance to main roads reflecting the accessibility, distance to sensitive land uses, and distance to electricity grids were created.

3) Developing a suitability index

To integrate various criteria for selecting the most suitable site for the solid waste incineration power plant, a composite suitability index was developed. The index consists of four main variables; namely: distance to sensitive land uses, distance to main roads, distance to solid waste transfer stations and landfill and distance to electricity grid. The suggested index aims at assessing various parts of the case study, in a numerical term, according to the considered criteria.

The created raster surfaces represented these four variables were firstly normalized. The raster surface of nearness to sensitive land uses was normalized according to the following formula:

$$
N x=\frac{X}{X_{\max }}
$$

where:

$X=$ Pixel value.

$N x=$ Normalized pixel value.

$X_{\max }=$ Maximum pixel value

While, the raster surfaces of the distance to landfill and transfer stations, nearness to grid and closeness to main roads were normalized according to the following formula: 


$$
N x=1-\frac{X}{X_{\max }}
$$

It should be noted that these two different normalization formulas are due to varied nature of the relationships between the considered variables and the suitability level. For example, while the suitability is positively correlated with the distance to sensitive land uses, i.e. distant locations are expected to be more suitable compared to close locations, suitability is negatively correlated with distance to landfill and transfer stations, distance to roads and distance to electricity grid, i.e. close locations are more suitable than distant locations.

Accordingly, the resulting pixel values of each individual normalized raster surface range between 0 and 1 , representing the least and highest levels of suitability, respectively. Finally, the composite suitability index was calculated through aggregating the four variables, using equal weight scheme, according to the following formula:

$$
S=\sum_{N x=1}^{N x=n}\left(N x \frac{1}{n}\right)
$$

where:

$S$ = Suitability index.

$N=$ Number of variables.

$N x=$ Normalized pixel value.

It should be noted that the application of equal weight scheme was decided due to the nature of various primary indicators (variables), which represent totally different dimensions or criteria of assessment and have no interrelationships. Also, such equal weight scheme was necessitated by relatively similar variations of these variables. Usually, more varied indicators (variables) provide wide range of options compared to less varied indicators. So that, the weight assigned for a certain criterion should reflect the range of different options provided by this criterion [22]. In this respect, the primary indicators (variables) of the suitability index were found to have relatively similar standard deviation ranging between 0.18 and 0.20 . This, accordingly, indicates that there is no significant difference between the considered criteria in terms of provided different options for siting solid waste power plant.

As a result of aggregating process, a raster surface was created with pixel values ranging between 0 for least suitable locations and 1 for most suitable locations.

4) Selecting the suitable site

This step involves applying the main exclusionary factor in the selection process, which is availability of land. For this purpose, the raster surface of composite suitability index generated in the previous step was masked by undeveloped and derelict land layer. Thereafter, different parts of the masked raster surface, that represent a number of appropriate sites, were classified and evaluated on the basis of their local characteristics to identify the most optimal site for the solid waste incineration power plants.

\section{Results and Discussion}

Each of the normalized raster surfaces of the developed criteria ranked various parts of Alexandria governorate, according to their suitability for siting the solid waste incineration power plant. According to the normalized distance to main roads, it was found that the eastern and central parts of Alexandria governorate show high levels of accessibility and therefore suitability with pixel values exceeding 0.900 . Meanwhile, accessibility decreases notably in both the westward and southwestward directions (Figure 3(a)). Accordingly, siting solid waste incineration power plant in the eastern and central parts of the governorate; highly accessible parts, can contribute to minimizing cost of solid waste transportation, and ensure regular and smooth transfer of solid waste.

Similarly, the eastern and central parts of the governorate have high values of normalized distance to landfill and transfer stations of solid waste. This is due to the skewed distribution of transfer stations, which are concentrated in central and eastern part of the governorate (Figure 3(b)). This creates an additional advantage for siting the solid waste incineration plant in these parts of the governorate as this would assist in minimizing solid waste transportation cost. Moreover, this can ensure cost-effective and environmentally-friend disposal of residues.

In contrast, western and southwestern parts of the governorate reveled high level of suitability according to distance to electricity grids with high value of normalized distance to electricity grids exceeding 0.920 (Figure 3(c)). Furthermore, the same parts have shown high values of normalized distance to sensitive land uses, as they are distant enough from sensitive land uses (Figure 3(d)). This also, emphasized the suitability of western and 
southwestern parts of the governorate for siting of the solid waste incineration power plant.

It should be noted that considering each criterion of analysis individually cannot provide comprehensive evaluation and might be misleading, especially as various criteria revealed contradicting results as shown in the preceding paragraph. In such a case, the composite suitability index can assist in avoiding such contradicting

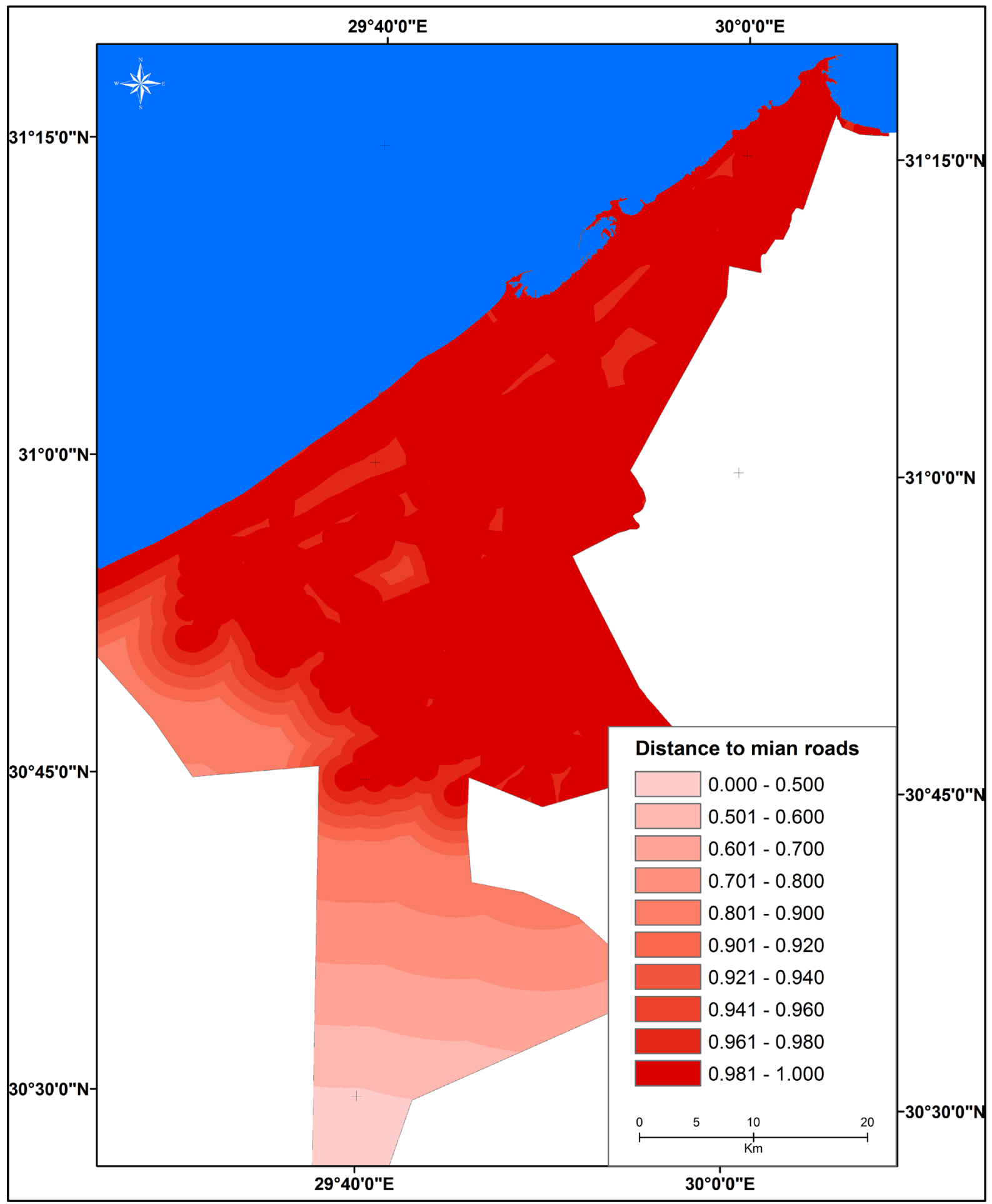




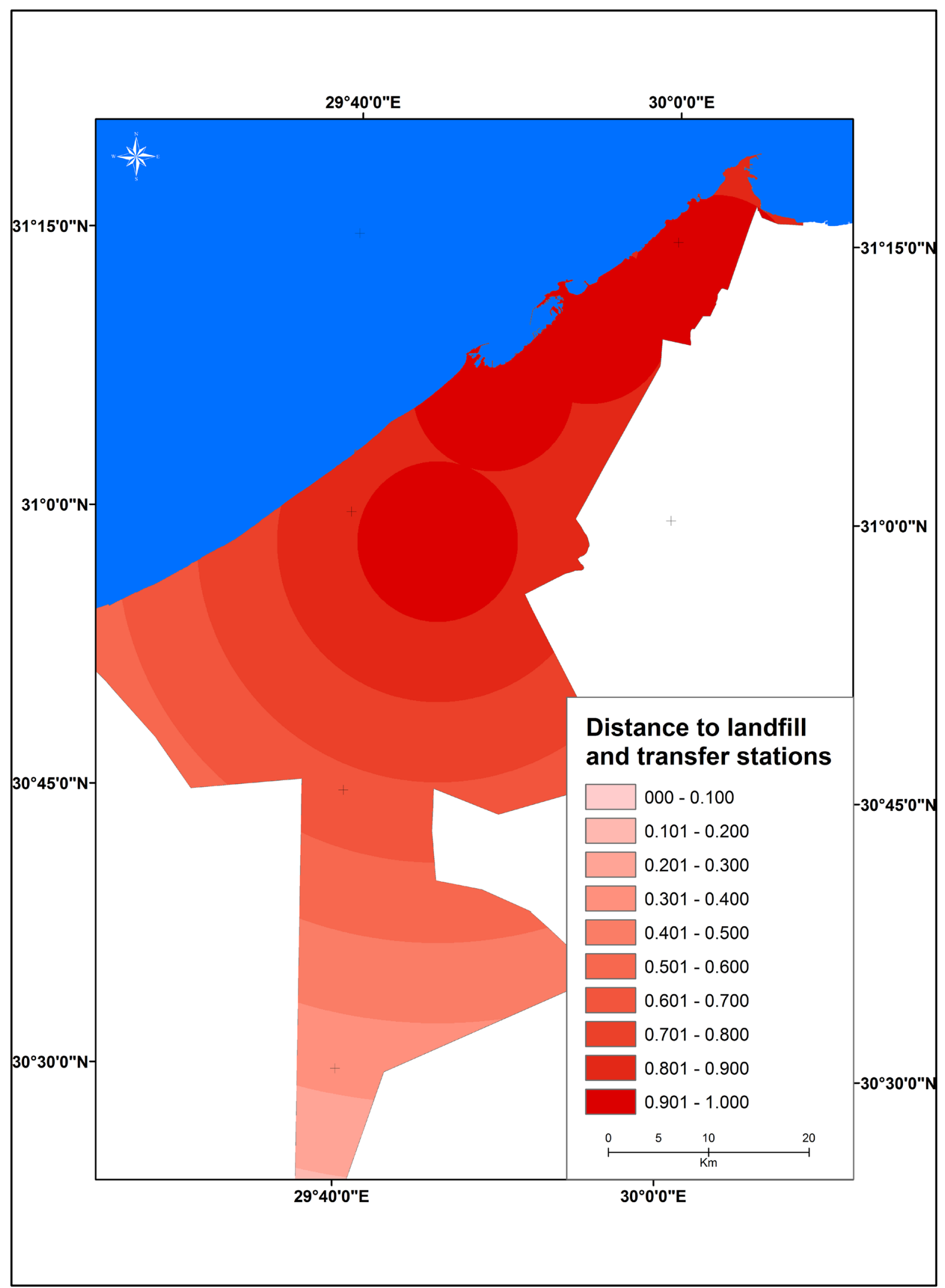

(b) 


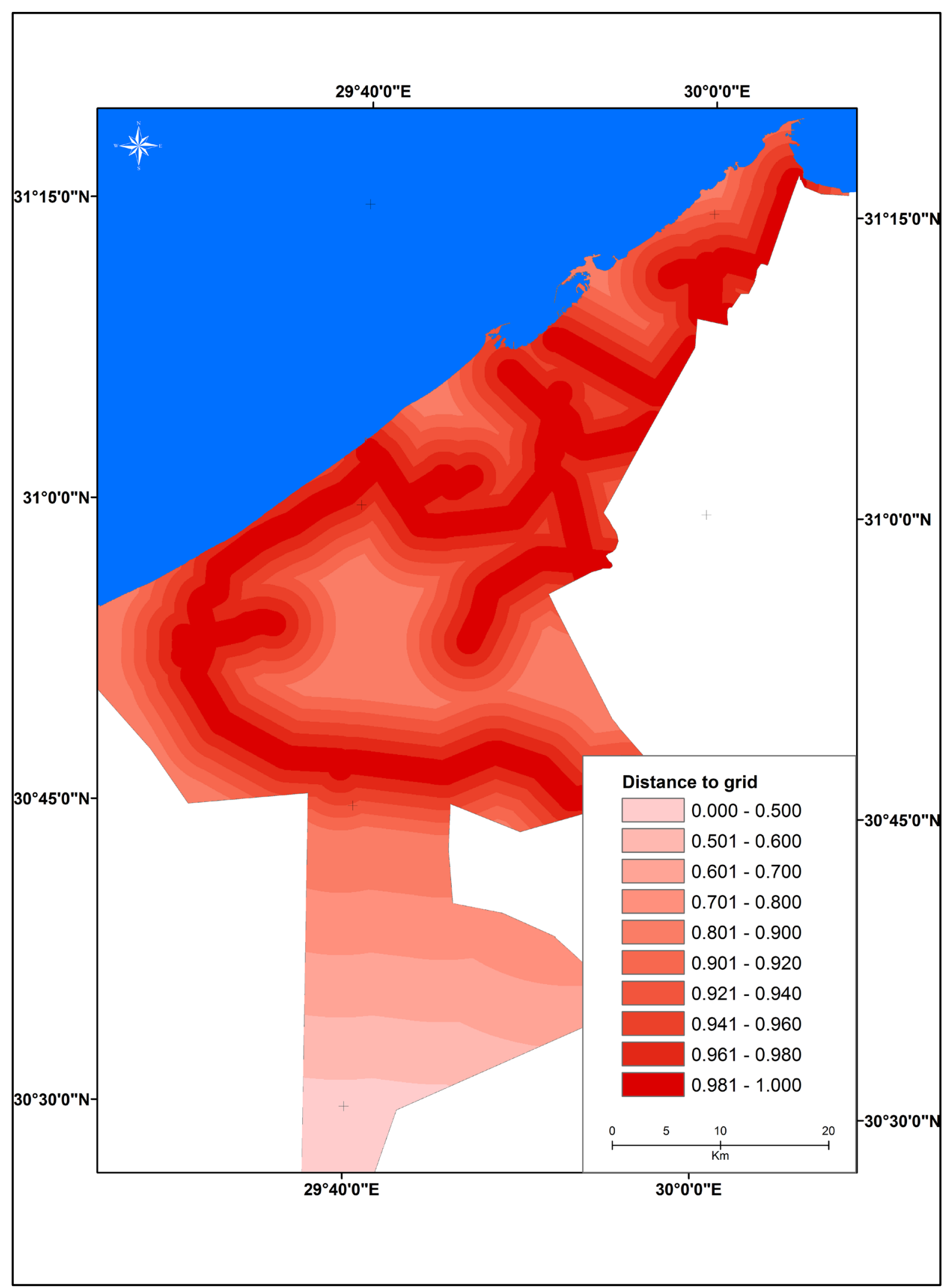

(c) 


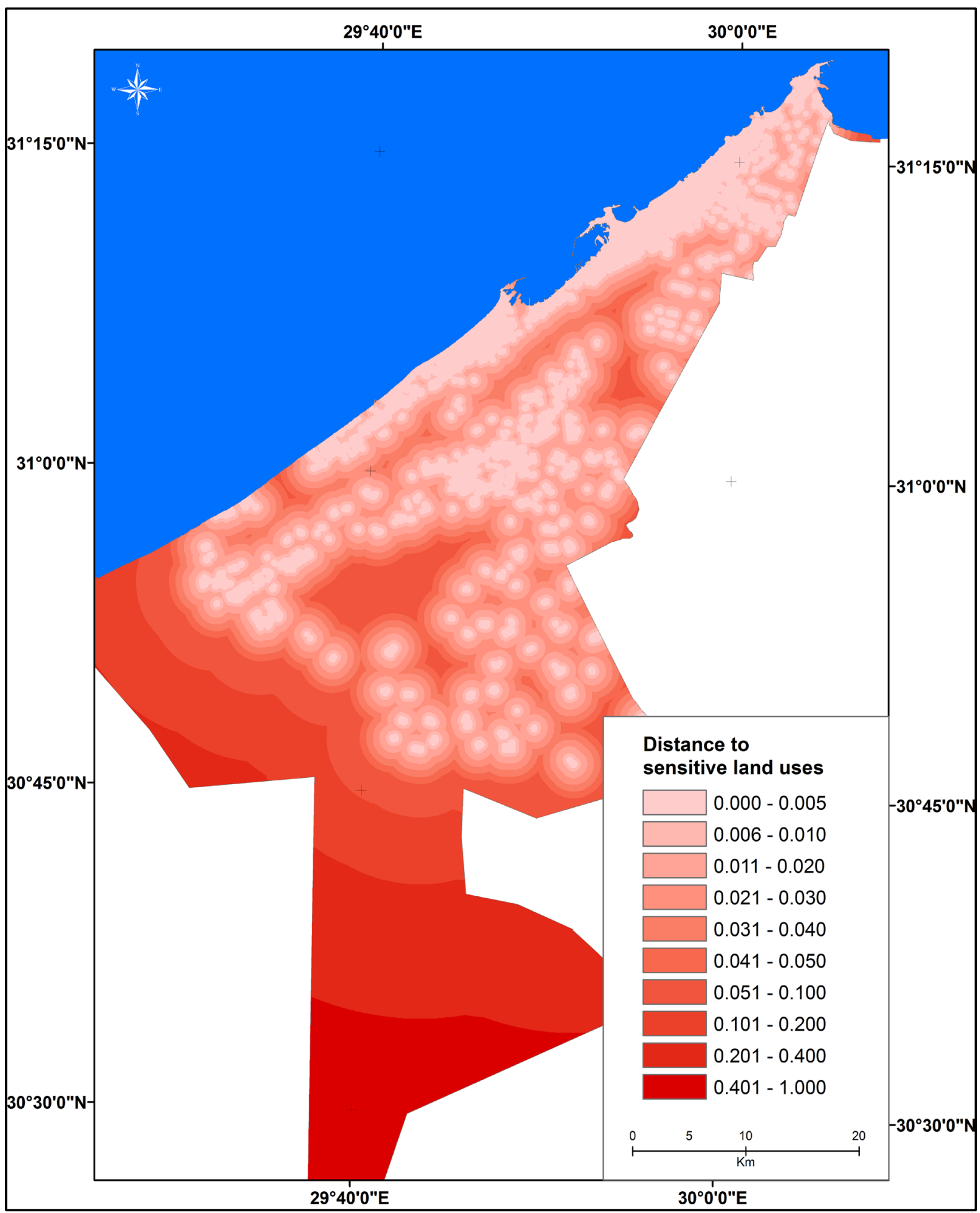

(d)

Figure 3. Spatial variations in the individual suitability criteria, in Alexandria.

results and ensure an integrated suitability analysis. The calculated values of the composite suitability index ranged between 0.250 and 0.755 , reflecting lowest and highest levels of suitability in Alexandria, respectively. Generally, the eastern and central parts of Alexandria governorate showed higher index value relative to the western 
and southwestern parts (Figure 4). It should be noted that the high index value prevailed in the eastern and central parts of Alexandria can be explained by their being high accessible and relatively close to landfill and transfer stations. Nevertheless, applying availability of land as an exclusionary criterion all eastern and southeastern parts of the governorate were excluded as they are already used and have no parcels of undeveloped or derelict land. Accordingly, the western and southwestern parts of Alexandria governorate were found suitable for siting solid waste incineration power plant.

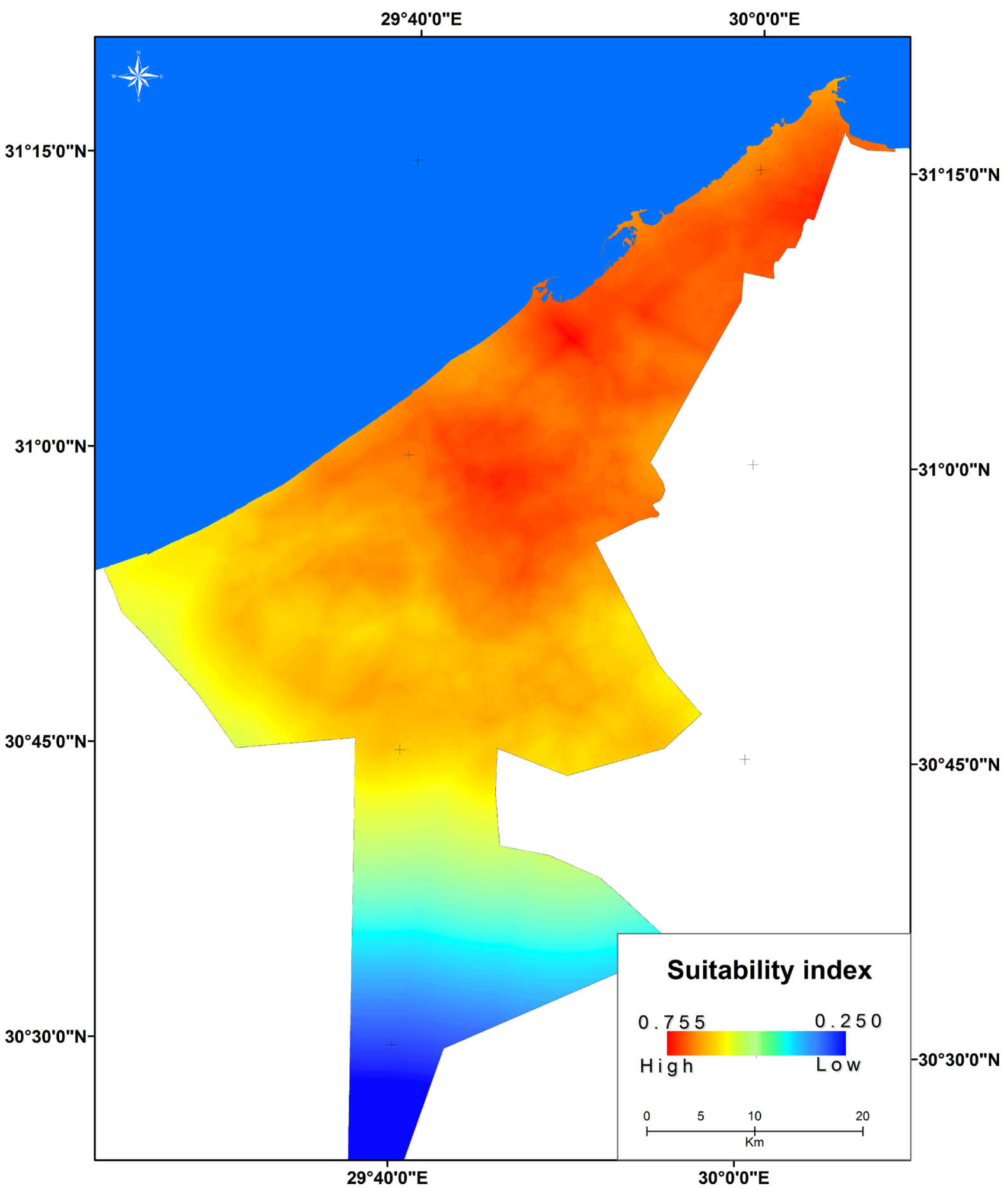

Figure 4. Spatial distribution of composite suitability index. 
These suitable parts were then reclassified according to their value of suitability index into three main categories; namely, most suitable parts with index value exceeding 0.6 , moderately suitable parts with index value ranging between 0.5 and 0.6 , and finally least suitable parts with index value below 0.5 (Figure 5). This classification is intended for highlighting the most suitable sites for the solid waste incineration power plant.

As a result of the classification, five sites were found to be highly suitable for siting solid waste incineration power plant. These sites cover a total area of $252.59 \mathrm{~km}^{2}$ located in El Amreyia and Burg El Arab districts in addition to New Burg El Arab city and adjacent desert area south west of Alexandria.

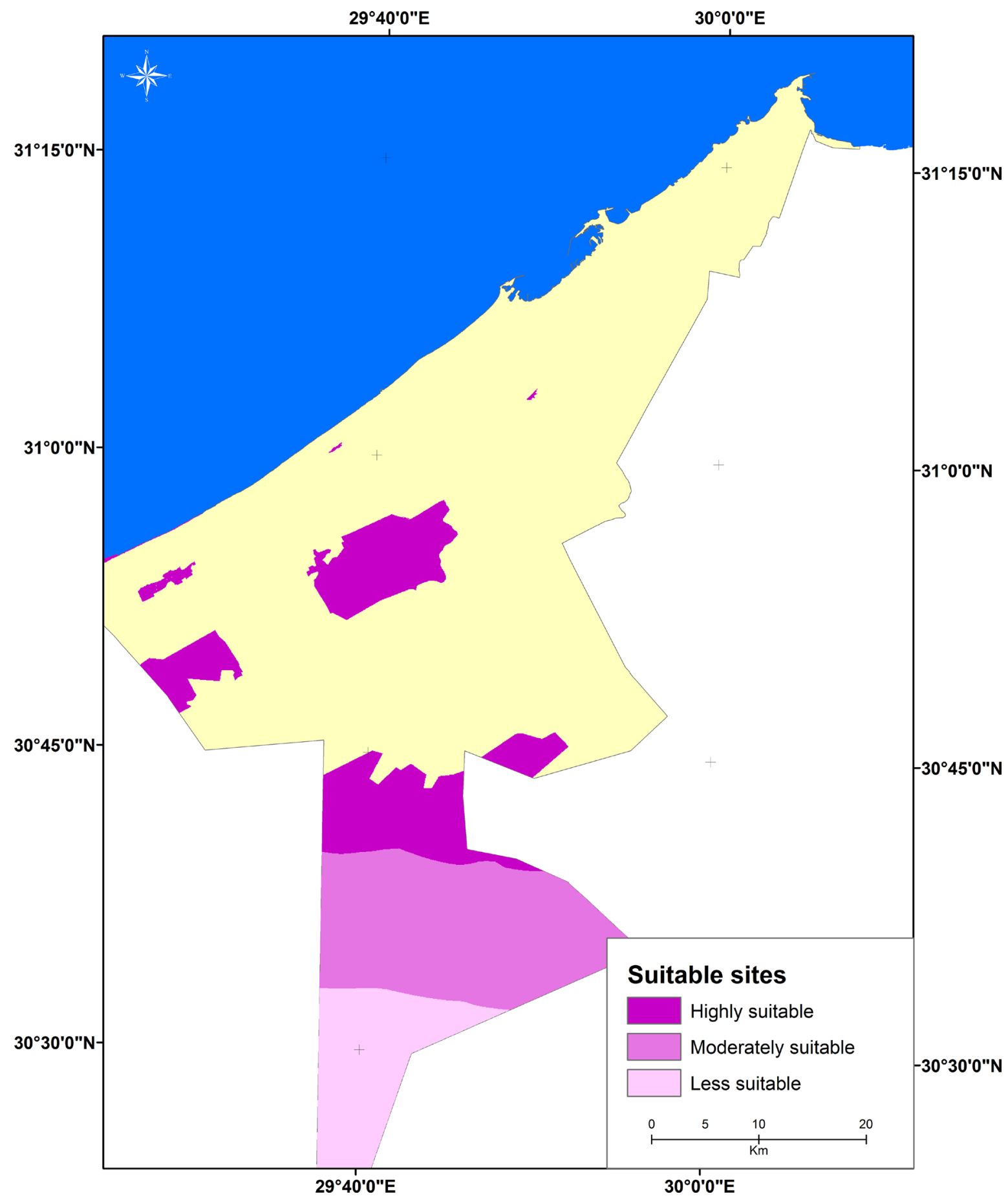

Figure 5. Potential sites for solid waste power station, classified according to their suitability levels. 
These highly suitable sites were, thereafter, evaluated according to site characteristics. In this context, it was found that three of these sites, suited to the northward of a number of human settlements and cultivated land, are not suitable for siting the solid waste power plant. This is mainly due to the dominant wind direction in the area, which is north to northwest. Accordingly these sites are located upwind of settlements and cultivated land and, consequently, may be adversely affected by any potential annoying factors produced by the solid waste incineration power station.

These suitable parts were then reclassified according to their value of suitability index into three main categories; namely, most suitable parts with index value exceeding 0.6 , moderately suitable parts with index value ranging between 0.5 and 0.6, and finally least suitable parts with index value below 0.5 (Figure 6) covering an

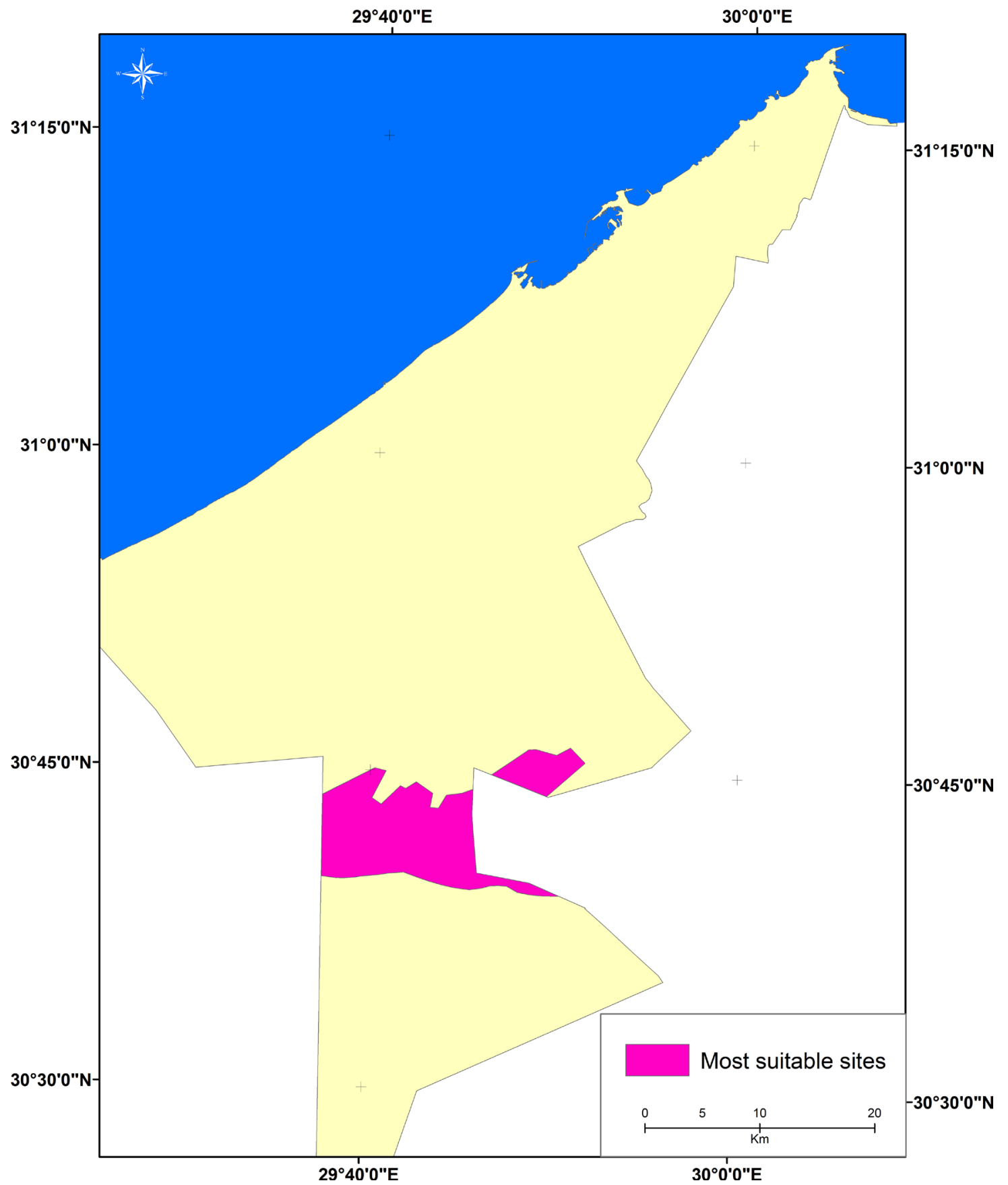

Figure 6. Most suitable parts of Alexandria for siting the solid waste power plant. 
area of $130 \mathrm{~km}^{2}$. These sites satisfy different site selection criteria and also are close to the landfill site, which means no additional cost for disposing residues from incineration power plant.

\section{Conclusions}

Utilization of municipal solid waste in electricity generation in Alexandria may support sustainability of the city as it contributes largely to decreasing the quantities of solid waste that need to be disposed, which means, in turn, prolonging the lifetime of the landfill. Moreover, this would increase the supply of electrical energy. Yet, improving efficiency of municipal solid waste management system can boost the feasibility of the power plant, as this would mean ensuring regular flow of solid waste for the power plant.

The developed methodology for siting solid waste incineration power plant considers a number of criteria in an integrated approach. The methodology provides, in a quantitative term, a measure for site suitability. This, in turn, can ensure a holistic suitability analysis for identifying most optimal sites for solid waste incineration power plant.

The application of the developed methodology assisted in identifying a number of suitable sites covering a total area of $252.59 \mathrm{~km}^{2}$ located mainly in the western and southwestern parts of Alexandria governorate. A closer site suitability analysis work identified two sites, located in the southwestern desert area, covering an area of about $130 \mathrm{~km}^{2}$ deemed to be optimal for siting of the incineration power plant.

It is worth mentioning that the suggested methodology, in the research work in hand, may be developed further by considering additional criteria such as impacts on traffic in urban areas and technical characteristics of the power plant, which were not the focus of this paper.

\section{References}

[1] Costi, P., Minciadri, R., Robba, M., Rovatti, M. and Sacile, R. (2004) An Environmentally Sustainable Decision Model for Urban Solid Waste Management. Waste Management, 24, 277-295. http://dx.doi.org/10.1016/S0956-053X(03)00126-0

[2] Fiorucci, P., Minciardi, R., Robba, M. and Sacile, R. (2003) Solid Waste Management in Urban Areas Development and Application of Decision Support System. Resources, Conservation and Recycling, 37, 301-328. http://dx.doi.org/10.1016/S0921-3449(02)00076-9

[3] Nakhla, D.A., Hassan, M.G. and El Haggar, S. (2013) Impact of Biomass in Egypt on Climate Change. Natural Science, 5, 678-684. http://dx.doi.org/10.4236/ns.2013.56083

[4] New Center for Integrated Studies of Land and Environment (2013) The Annual Report for Solid Waste Management in Egypt. Ministry of State for Environmental Affairs, Cairo.

[5] UNESCO (1999) Encyclopedia of Life Support Systems, Theme 4.13: Waste Management \& Minimisation, Section 4.13.4.2. Solid Wastes for Power Generation. John Wiley \& Sons Ltd., Hoboken.

[6] Malczewski, J. (2004) GIS-Based Land-Use Suitability Analysis: A Critical Overview. Progress in Planning, 62, 3-65. http://dx.doi.org/10.1016/j.progress.2003.09.002

[7] World Bank (1999) Municipal Solid Waste Incineration. The World Bank, Washington DC.

[8] Turner, K. (2002) Site Selection and Evaluation Criteria for an Early Site Permit Application. EPRI, Palo Alto.

[9] Shi, X., Elmore, A., Li, X., Gorence, N. J., Jin, H., Zhang, X., et al. (2008) Using Spatial Information Technologies to Select Sites for Biomass Power Plants: A Case Study of Guangdong Province, China. Biomass and Bioenergy, 32, 3543. http://dx.doi.org/10.1016/j.biombioe.2007.06.008

[10] Tavares, B., Zsigraiova, Z. and Semiao, V. (2011) Multi-Criteria GIS-Based Siting of an Incineration Plant for Municipal Solid Waste. Waste Management, 31, 1960-1972. http://dx.doi.org/10.1016/j.wasman.2011.04.013

[11] Abudeif, A.M., Abdel Moneim, A.A. and Farrag, A.F. (2015) Multicriteria Decision Analysis Based on Anlytic Heirarchy Process in GIS Environment for Siting Nuclear Power Plant in Egypt. Annals of Nuclear Energy, 75, 682-692. http://dx.doi.org/10.1016/j.anucene.2014.09.024

[12] Fernandez-Jimenez, L.A., Mendoza-Villena, M., Zorzano-Santamaria, P., Garcia-Garrido, E., Lara-Santillan, P., Zorzano-Alba, E., et al. (2015) Site Selection for New PV Power Plants Based on Their Observability. Renewable Energy, 78, 7-15. http://dx.doi.org/10.1016/j.renene.2014.12.063

[13] Nazli, A.Y., Kentel, E. and Duzgun, H.S. (2013) GIS-Based Site Slection Methodology for Hybird Renewable Energy Systems: A Case Study from Western Turkey. Energy Conversion and Management, 70, 90-106. http://dx.doi.org/10.1016/j.enconman.2013.02.004 
[14] Sanchez-Lozano, J.M., Garcia-Cascales, M.S. and Lamata, M.T. (2014) Identification and Selection of Potential Sites for Onshore Wind Farms Development in Region of Murica, Spain. Energy, 73, 311-324. http://dx.doi.org/10.1016/j.energy.2014.06.024

[15] Satkin, M., Noorollahi, Y., Abbaspour, M. and Yousefi, H. (2014) Multi Criteria Site Selection Model for WindCompressed Air Energy Storage Power Plants in Iran. Renewable and Sustainable Energy Reviews, 32, 579-590. http://dx.doi.org/10.1016/j.rser.2014.01.054

[16] Uyan, M. (2013) GIS-Based Solar Farms Site Selection Using Analytic Hierarchy Process (AHP) in Karapinar Region, Konya/Turkey. Renewable and Sustainable Energy Reviews, 28, 11-17. http://dx.doi.org/10.1016/j.rser.2013.07.042

[17] Zhou, Y., Wu, W.X. and Liu, G.X. (2011) Assessment of Onshore Wind Energy Resource and Wind-Generated Electricity Potential in Jiangsu, China. Energy Procedia, 5, 418-422. http://dx.doi.org/10.1016/j.egypro.2011.03.072

[18] CAPMAS (2013) Egypt in Figures 2013. Central Agency for Public Mobilization and Statistics. CAMPAS, Cairo.

[19] Royal Haskoning (2007) Alexandria Development Project Integrated Environmental and Social Impact Assessment. Alexandria Governorate, Alexandria.

[20] SWEEPNET (2010) Country Report on the Solid Waste Management in Egypt. The Regional Solid Waste Exchange of Information and Expertise Network in Mashreq and Maghreb Countries. SWEEPNET, Cairo.

[21] Hu, H., Li, X., Nguyen, A.D. and Kavan, P. (2015) A Crtitical Evaluation of Waste Incineration Plants in Wuhan (China) Based on Site Selection, Environmental Influence, Public Health and Public Participation. International Journal of Environmental Research and Public Health, 12, 7593-7614. http://dx.doi.org/10.3390/ijerph120707593

[22] Department for Communities and Local Government (2009) Multi-Criteria Analysis: A Manual. Communities and Local Government Publications, London. 